\title{
A Method of English Ability-Grouping Teaching in a University of Technology
}

\author{
Chin-Ling Lee and Cheng-Jian Lin
}

\begin{abstract}
The problem of students with various English proficiency levels in a class has been a major obstacle for English teaching and learning. Therefore, educators and researchers have studied the effects of ability-grouping teaching on English teaching in recent years, but there are still few findings from research based on experimental teaching or real practice of English ability-grouping teaching. This study investigated a practical implementation in terms of program planning, instruction, and evaluation in a university of technology in central Taiwan, using a fuzzy competitive learning technique. The results indicated that the application of English ability-grouping teaching could solve the problems which had been challenging English teachers with the diversity of language proficiency levels of students in a class. Students accepted the new teaching strategy and felt intermediately satisfied with the ability-grouping teaching.
\end{abstract}

Index Terms - English teaching, fuzzy competitive learning technique, English ability-grouping teaching.

\section{INTRODUCTION}

\section{A. Motivation of Research}

The effectiveness of English teaching and learning in technological education have been criticized for years in spite of the significantly shorter class hours aligned in the curriculum than those in the general education, due to the attempt of professional skills training and the considering English teaching as one of academic subjects. Eventually, those in the workplace are unable to meet the need of global communication, while those making efforts on the further study have much difficulty on reading comprehension of English textbooks. Results from a vast range of studies on the major causes of unsatisfactory effectiveness of English teaching in technological education are found to be the careless curriculum design and school policies of administration. The curriculum design, on the one hand, is cause for problems of inefficient teaching, which include shortage of teaching hours, hard-achieving instructional goals, and textbooks selection. On the other hand, the administrative policies in school pay less attention to English

Manuscript received October 13, 2012; revised January 15, 2013. This work was supported in part by the National Science Council of the Republic of China, Taiwan for financially supporting this research under Contract No. NSC 101-2221-E-167-037.

C. L. Lee is with the International Trade Department, National Taichung University of Science and Technology, Taichung City, Taiwan 404, ROC (e-mail: merrylee@nutc.edu.tw).

C. J. Lin is with the Computer Science and Information Engineering Department, National Chin-Yi University of Technology, Taichung City, Taiwan 411, ROC. (e-mail:cjlin@ncut.edu.tw). education [1].

Hung and Luou [2] also undertook a large-scale survey on the English education in vocational high schools to investigate the dilemma of English teaching and suggestions from teachers of English. The major findings illustrated a great number of teachers argued the diversity of English proficiency levels among students in a class, which brought a big challenge for efficient teaching [3]-[8]. As to the feasible solutions for work, the favorable suggestion was "the ability-grouping teaching." Moreover, Lee [9] reviewed related studies [10]-[14] and concluded that ability-grouping teaching could be the top priority and strategy to increase the effectiveness of English teaching owing to the shortage of educational resources resulting in big class-size teaching and the diverse English proficiency among students as well [15], [16].

\section{B. Purposes of Research}

In order to improve English teaching quality and to turn students' frustration into success, the purpose of the study was aimed 1) to investigate the practical problems challenging teachers' teaching in EFL classroom 2) to create a practical ability-grouping teaching program as a change of instructional policy 3) to establish a learning organization for teachers to sharpen their teaching skills, and 4) to increase students' learning motivation and elevate the teaching effectiveness.

\section{Research Questions}

Based on the above-mentioned research purposes and the synthesized review of the relevant literature, the research questions were presented as the following.

1) What is the feasible and practical to initiate an English ability-grouping teaching in the technological college?

2) What perception do students gain on the English ability-grouping teaching program according to different demographic variables (class rank and gender)?

\section{LITERATURE REVIEW}

\section{A. Urge of English Ability-Grouping Teaching}

Ability-grouping teaching has placed more attention to the English instruction in Taiwan. English education is usually considered as an important subject in academic performance, and the age of school students starting to learn is on the third grade about 10 years old. It is inevitable to face a diversity of English proficiency of students in a college class; especially with respect to four language skills - listening, speaking, reading, and writing. A challenge to teachers of English is setting the teaching goal [17]. Therefore, Lee [9] argued the 
disadvantages of norm-distribution of students' English proficiency levels in a class. He illustrated the advantages of English ability-grouping teaching as 1) to conform to the adaptive learning, 2) to meet the needs of diverse students, and 3 ) to increase the teaching and learning efficacy.

\section{B. English Ability-Grouping Teaching}

Top priority of planning English ability-grouping teaching is to deal with the questions: how to do the grouping task, how to avoid labeling students by language abilities, how to incorporate with administrative support, and how to change the viewpoint of parents [18]. All the priorities need to be concerned and well prepared for, and can a sound structure of a teaching model be feasibly and practically generated.

\section{Group Formation}

Group formation has been illustrated as a major factor affecting the group teaching and learning. A vast number of studies [4], [14], [19]-[21] show the interest in the effects of group formation on the achievement performance of learners. As for the group formation of the English ability-grouping teaching, the major concern is to conform to the request of forming students with similar or identical proficiency level in a class. In recent years, colleges has usually adopted the grouping task by administering placement tests, most including reading and listening comprehension for the average mean of the scores; then clustering those students into a class with the similar average mean. However, English proficiency contains more than that with the respect to four language skills, and grouping based on the average mean scores is not able to control the number of students in an individual class.

\section{Methodology}

\section{A. Fuzzy Competitive Learning Techniques}

Forming students with similar English proficiency in a class can resolve the teaching difficulty in large class and provide with adaptive learning. However, colleges usually implement the grouping task using the mean scores of students' placement tests on reading and listening. Since studnets are classified with the same mean scores, there still show the variety of students' English abilitites on four language skills. Lee [21] presented an intelligent grouping method to cluster students' language characteristics so that students with the same language proficiency could be assigned in the same class; on the other hand the number of students in a class could be controlled, too.

Based on the distribution of all students' scores from each language skill test, the fuzzy competitive learning netweork classfies each student's scores gained from each test into one of the specified $\mathrm{n}$ class. In the fuzzy competitive learning network (see Fig. 1), there was a single layer of output units $O_{i}$, each full connected to a set of input $\mathrm{x}_{\mathrm{j}}$ via connections $w_{i j}$ Output units meant the number of the class. Input $x_{j}$ meant the $j$ th student's scores from each test. Output unit i emitted signal $O_{i}=\mu_{i}^{k}$ belonged to $[0,1]$ for the current input $x^{k}$ (student's scores). The membership function $\mu_{i}$ of output unit $i$ was completely characterized by the corresponding weight vector $w_{i}$. Note that these membership functions could not be arbitrarily specified to ensure that $\sum_{i=1}^{c} \mu\left(x_{i}^{k}\right)=1$ for every student $k$. That was, the total membership of student $k$ has to be normalized to 1 . The selection of membership functions $\mu_{i}$ depended on the particular dissimilarity measure of interest and therefore determined the objective function that was optimized. The difference between the fuzzy competitive learning and the traditional competitive learning was that more freedom was exercised in selecting $\mu_{i}$ functions.

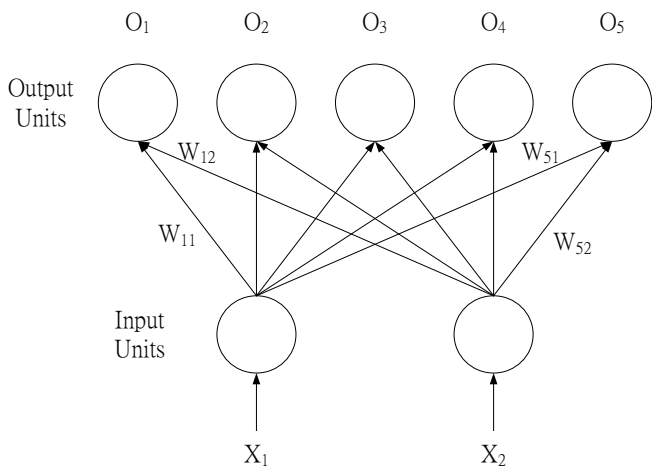

Fig. 1. The kohonen network.

The proposed fuzzy competitive learning algorithm was summarized as follows. For each learning step a student's score was chosen randomly and was presented to the fuzzy neural network. The connections to each output unit carried a weight vector $w_{i}$ and for each learning step these weight vector were adjusted towards their respective fuzzy cluster centers by the following two steps:

1) For all $i$, compute cluster membership grade $\mu_{i}^{k}$

$$
\mu_{i}^{k}=\frac{\left(\left\|x^{k}-w_{i}\right\|^{2}\right)^{-\alpha}}{\sum_{l=1}^{c}\left(\left\|x^{k}-w_{l}\right\|^{2}\right)^{-\alpha}}
$$

where $\alpha>0$ is the weighting exponent.

2) For all $i, j$, adjust weights $w_{i j}$ by

$$
w_{i j}^{\text {new }}=w_{i j}^{\text {old }}+\eta \mu_{i}^{k}\left(x_{j}^{k}-w_{i j}^{\text {old }}\right) .
$$

The term $\eta$ determined the learning rate. If the $\eta$ was selected larger, the convergence would be faster; otherwise, it would be slower. After sufficient learning, and assuming that the input student's scores were sufficiently distinct to find one of the clusters. In this system, whenever a student's scores were input, the output nodes might determine which membership grade the student belonged to for the user, who might take the advantage of the message to create the distribution of every student for the best result. In the traditional neural network case, each student's $x$ score can belong to only one class.

On the contrary, each student's $x^{k}$ score could belong to several classes, to different degree in the fuzzy neural network case. The researcher considered that the ith output unit (the $i$ th class) could generate membership grade $\mu_{i}^{k}$, according to the current student's $x^{k}$ score and weight vector $w_{i}$. In this way, fuzzy competitive learning is a generalization 
of competitive learning for multiple continuous-valued "winners." However, nothing much would be gained if processing step of cluster-membership representation, because of the decision in favor of one specific cluster (class), usually the one with the largest membership grade. In the educational system, the student number of each class should be equally controlled for the fair distribution of educational resources. In this case, only membership grade could do the great help using the degree of it to determine which student might also be clustered to different other class. For example, the degree of membership grade resulting that a student belonged to A class was 0.8 and to class B is 0.7 , then the student could be clustered to either class A or class B since the little difference between 0.8 and 0.7 .

TABLE I: CLUSTERING RESULTS By USING VARIOUS METHODS

\begin{tabular}{|c|c|c|c|c|c|c|c|c|}
\hline $\begin{array}{c}\text { N } \\
\text { O. }\end{array}$ & \multicolumn{2}{|c|}{ Skill ability } & \multicolumn{2}{|c|}{ Fuzzy Competitive Network } & $\begin{array}{c}\text { Competitive } \\
\text { Network }\end{array}$ & $\begin{array}{c}\text { Mean } \\
\text { Value }\end{array}$ \\
\hline & $\begin{array}{c}\text { Read- } \\
\text { ing }\end{array}$ & $\begin{array}{c}\text { Listen- } \\
\text { ing }\end{array}$ & $\mu_{\mathrm{A}}$ & $\mu_{\mathrm{B}}$ & $\mu_{\mathrm{C}}$ & $\begin{array}{c}\mu_{\mathrm{MA}} \\
\mathrm{x}\end{array}$ & & \\
\hline 1 & 12 & 17 & $\begin{array}{c}0.3172 \\
21\end{array}$ & $\begin{array}{c}0.66866 \\
7\end{array}$ & $\begin{array}{c}0.01411 \\
2\end{array}$ & $\mathrm{~B}$ & $\mathrm{~B}$ & $\mathrm{~B}$ \\
\hline 2 & 35 & 21 & $\begin{array}{c}0.0061 \\
03\end{array}$ & $\begin{array}{c}0.99358 \\
9\end{array}$ & $\begin{array}{c}0.00030 \\
8\end{array}$ & $\mathrm{~B}$ & $\mathrm{~B}$ & $\mathrm{~B}$ \\
\hline. &. &. &. &. &. &. &. & $\mathrm{B}$ \\
\hline 15 & 3 & 13 & $\begin{array}{c}0.4843 \\
37\end{array}$ & $\begin{array}{c}0.50501 \\
5\end{array}$ & $\begin{array}{c}0.01064 \\
8\end{array}$ & $\mathrm{~B}$ & $\mathrm{~A}$ & $\mathrm{~B}$ \\
\hline 16 & 17 & 80 & $\begin{array}{c}0.9971 \\
77\end{array}$ & 0.00081 & $\begin{array}{c}0.00201 \\
2\end{array}$ & $\mathrm{~A}$ & $\mathrm{~A}$ & $\mathrm{~A}$ \\
\hline 18 & 55 & 51 & $\begin{array}{c}0.2179 \\
52\end{array}$ & $\begin{array}{c}0.40029 \\
9\end{array}$ & $\begin{array}{c}0.38174 \\
9\end{array}$ & $\mathrm{~B}$ & $\mathrm{~B}$ & $\mathrm{~A}$ \\
\hline
\end{tabular}

In Table I, after inputting the students' scores on the tests of reading and listening, $\mu_{\mathrm{A}}, \mu_{\mathrm{B}}$, and $\mu_{\mathrm{C}}$ were generated to separately represent the extent of which particular group they belong to. Take No. 15 as an example. By comparing the each $\mu$ values, this student may be clustered into group A or B, but not is definitely strict to be in either group A or B. In this way, it is greatly helpful to adjust the number of each group to cope with equal number of each group.

\section{B. Questionnaire Survey}

A questionnaire on learning satisfaction was utilized to collect the participants' perspectives and perception on the English-ability grouping teaching at the end of the semester. Participants self-reported their likes and dislikes on the new teaching strategy. Moreover, they can also express the viewpoint of the adoptive learning in an open-ended question.

\section{Data Collection and Analysis}

Totally 842 freshmen participated in the research to initiate the English ability-grouping teaching. Moreover, 9 teachers of English joined the program in charge of the instruction and some administrative task.

An on-line achievement test based on a standarized English proficiency test was adopted to evaluate how much progress the students made. The SPSS software package for window was utilized to analyze the data collected from the tests. The reliability and validity of the tests were high according to the reports from the on-line test company.
Moreover, a teacher-made questionnaire was used to explore the perception and viewpoints students held and whether or not they felt satisfied with the new teaching strategy. In total, 842 questionnaires were returned from 963 participants that presented a response rate of $87.4 \%$ and were analyzed for the results.

\section{Research Structure}

The structure of the present study was illustrated as the following Fig. 2.

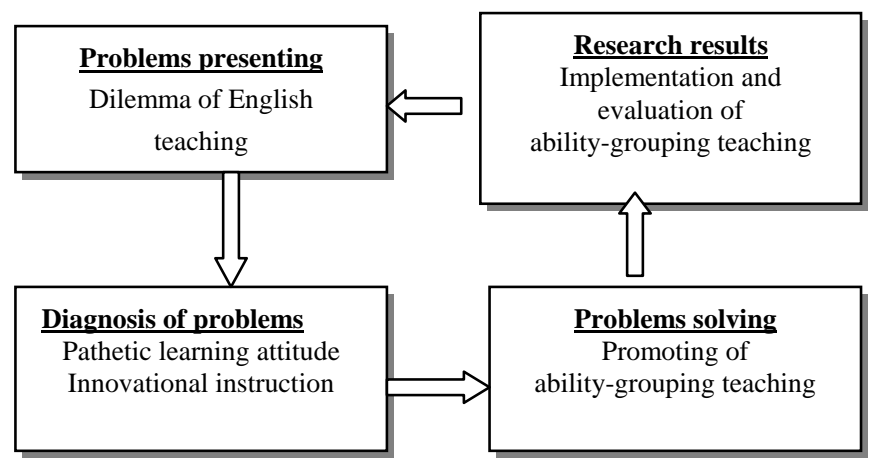

Fig. 2. Flowchart of research action on English ability-grouping teaching.

\section{E. Research Procedure}

A cycling procedure was placed to form and complete the constant innovational instruction in the study. The research procedures of the present study followed the features of action research shown as follows.

1) To identify the current problems: According to the number of certificates on the General English Proficiency Test (GEPT) or other relevant English certificates gained by our students was lower than what was expected, the learning motivation of the students needed to be increased for better performance.

2) To diagnose the problems: The students in the target technical college had been showing an apathetic learning attitude, which was the casualty of low learning motivation. Moreover, the teachers had faced the challenge of big class teaching and students with a variety of proficiency levels. In the step, the problems could be constantly modified by means of reviewing relevant literature and theories to draw a draft of the project.

3) To solve problems: In order to solve the problems presented above, the teacher as the research provided a new instruction - an English ability-grouping teaching in hope that the innovational instruction could improve the disadvantages of traditional grouping method and generate its effectiveness.

4) To present and evaluate research results: The major findings of the research would contain the fact of students' performance pertaining to achievement tests, and self-reporting questionnaire. Moreover, the results also reflected the limitation of the program, which would be presented as new problems to be improved for initiating the following project.

\section{RESUlts}

This study was a descriptive study to investigate the nature 
of current English ability-grouping teaching programs in Taiwan through the researcher's practical administration and the participating students' perception of learning attitudes and satisfaction. The results of the statistical analyses of the data collected from the survey questionnaire were precisely presented.

The two-way ANOVA, using the variance analysis method to deal with two independent variables, is utilized not only to explore the main effects of each individual independent variable, about also to find out if any interaction effect of the two variables exists.

Paticipants were 842 students who responded to the questionnaire, 187 students $(22.75 \%)$ in Class rank A, 465 $(56.57 \%)$ in Class rank B, and $190(20.68 \%)$ in Class rank C; moreover, there were 610 male students $(74.21 \%)$ and 232 female students $(25.79 \%)$ in the English ability-grouping teaching program. Totally there were 822 students returned the responses of the questionnaire to self-report their perception on the learning satisfaction.

TABLE II: SUMMARY OF TWO-WAY ANOVA OF THE EFFECTS OF GENDER

\begin{tabular}{cccccc}
\multicolumn{5}{c}{ AND CLASS RANK ON STUDENTS' LEARNING SATISFACTION } \\
\hline Source & SS & Df & MS & F & Sig. \\
\hline CLASS RANK & 2.583 & 2 & 1.292 & 7.511 & .001 \\
GENDER & .109 & 1 & .109 & .635 & .426 \\
CLASS RANK * & 1.362 & 2 & .681 & 3.959 & .019 \\
GENDER & & & & & \\
Error & 140.324 & 836 & .172 & & \\
Corrected Total & 146.043 & 842 & & & \\
\hline a R Squared =.039 (Adjusted R Squared $=.033) ; \mathrm{p}<.05$ &
\end{tabular}

Table II showed the summary of tests of between-subjects effects, illustrating there was a significant interaction effect between different class ranks and gender $\left(\mathrm{F}=3.959^{*}, \mathrm{p}\right.$ $=.019<.05)$. Although one of the main effects of two independent variables was significant, Class Rank $(\mathrm{F}=$ $\left.7.511^{*}\right)$ and Gender $(\mathrm{F}=.635)$, the result of the interaction effect of the two variables needed to explore their individual simple main effect and the posteriori comparisons. Therefore, a further ANOVA was administered determining the simple main effect and the post hoc test for the two specific factors, class rank and gender.

TABLE III. SUMMARY OF ANOVA OF THE SimPLE MAIN EFFECTS OF GENDER AND CLASS RANK ON STUDENTS' LEARNING SATISFACTION

\begin{tabular}{|c|c|c|c|c|c|}
\hline Source & $\begin{array}{l}\text { Type III } \\
\text { SS }\end{array}$ & Df & $\mathrm{F}$ & Sig. & $\begin{array}{c}\text { Posteriori } \\
\text { Comparisons }\end{array}$ \\
\hline Male (a1) & 4.011 & 2 & $10.86^{* *}$ & .000 & $\begin{array}{l}\mathrm{C}>\mathrm{A} \\
\mathrm{C}>\mathrm{B}\end{array}$ \\
\hline Female (a2) & 1.691 & 2 & $6.361 *$ & .002 & $\begin{array}{l}\mathrm{C}>\mathrm{A} \\
\mathrm{B}>\mathrm{A}\end{array}$ \\
\hline Class rank (b1) & .598 & 1 & $4.416^{*}$ & .037 & $\mathrm{M}>\mathrm{F}$ \\
\hline Class rank (b2) & .671 & 1 & 3.740 & .054 & N.S. \\
\hline Class rank (b3) & $9.746 \mathrm{E}-02$ & 1 & .508 & .477 & N.S. \\
\hline
\end{tabular}

According to Table III, among male students of Class rank variable, the simple main effect showed significantly, $\mathrm{F}=$ $10.816 * *$. From the result of the posteriori comparisons, the Class rank $\mathrm{C}(\mathrm{N}=137, \mathrm{M}=3.3291)$ was significantly higher than Class rank A $(\mathrm{N}=119, \mathrm{M}=3.1597)$ and Class rank $\mathrm{B}$ $(\mathrm{N}=354, \mathrm{M}=3.1292)$. The result indicated that male students in Class rank $\mathrm{C}$ held significantly higher degree of learning satisfaction than those male students in Class rand A and B.
Among female students of Class rank variable, the simple main effect showed significantly, $\mathrm{F}=6.361 *$. From the result of the posteriori comparisons, the Class rank $\mathrm{C}(\mathrm{N}=33, \mathrm{M}=$ 3.2686) was significantly higher than Class rank $A(N=68$, $\mathrm{M}=3.0421)$; while Class rank $\mathrm{B}(\mathrm{N}=111, \mathrm{M}=3.2183)$ was also significantly higher than Class rank $\mathrm{A}$. The result indicated that female students in Class rank $\mathrm{C}$ held significantly higher degree of learning satisfaction than those female students in Class rank A; however female students in Class rank B also held significantly higher degree of learning satisfaction than those female students in Class rank A. On the other hand, among students in Class rank A of Gender variable, the simple main effect showed significantly, $\mathrm{F}=4.416^{*}$. From the result of the posteriori comparisons, the male students in Class rank A $(\mathrm{N}=119, \mathrm{M}=3.1597)$ held significantly higher degree of learning satisfaction than those female students in Class rank A $(\mathrm{N}=68, \mathrm{M}=3.0421)$. Among students in Class rank B of Gender variable, the simple main effect showed insignificantly, $F=3.740$. The male students in Class rank B $(\mathrm{N}=354, \mathrm{M}=3.1292)$ held no difference on the degree of learning satisfaction from that those female students in Class rank $\mathrm{B}(\mathrm{N}=111, \mathrm{M}=3.2183)$ did. Among students in Class rank $\mathrm{C}$ of Gender variable, the simple main effect showed insignificantly, $\mathrm{F}=.508$. The male students in Class rank $\mathrm{C}(\mathrm{N}=137, \mathrm{M}=3.3291)$ held no difference on the degree of learning satisfaction from that those female students in Class rank $\mathrm{C}(\mathrm{N}=33, \mathrm{M}=3.2686)$ did.

\section{CONCLUSIONS AND RECOMMENDATION}

With the respect to the English proficiency of the target university students, the above-mentioned major findings were further delineated, explained as follows. First, students performed much better on English listening comprehension than speaking one at the beginning and after the English ability-grouping learning program. The findings referred to the fact that the need of instruction on English reading strategies was urgent. Moreover, the other findings revealed that the passing rate on two reading tests for college students did not show better performance than that for junior college students. That would be a surprise that these college students did not take advantage of three more years on English learning while they were studying in vocational high school. It is necessary and important to investigate the English instruction in vocational high school and to provide remedial instruction to the low-achieving high school students. As to the intermediate degree of students' satisfaction with English ability-grouping teaching program, students at each level, such as high-achieving, intermediate, and low-achieving level, showed their acceptance to the new teaching strategy. Nevertheless, the students at low-achieving level showed significantly higher degree of satisfaction indicating that these low-achievers would not have as much stress and apprehension from learning with high-achievers as they did before, and they could like to learn with other students at similar proficiency level. Therefore, it is even more important to design adaptive learning materials and activities for the students to fit their learning abilities.

The English ability-grouping teaching program has been adopted in many technological colleges and universities in 
these years in Taiwan. However, not much research showed interest in investigating the alignment, implementation, and results. The results of the study can reveal that the English ability-grouping teaching program can provide students with adaptive learning environment to meet the needs of students with diverse English proficiency. Furthermore, students in technological education have been criticized that they are lack of the English reading ability, which places restriction on the knowledge retrieving from English texts, especially on the further study in the graduate school. Therefore, an English reading strategy instruction for students in technological college/university is strongly recommended.

\section{REFERENCES}

[1] M. S. Lin, "The comparison study on English teaching in vocational and general high schools in R.O.C.," in Proc.Twelfth ESL International Conference in R.O.C., Taipei, 1996, pp. 59-79.

[2] C. H. Hung and B. C. Luou, "A study of the perspectives on English education among English teachers in vocational high school," in Proc. National Academic Conference on English Teaching in Technological Education, 1995, pp. 121-145.

[3] C. K. Cheung and E. Rudowica, "Academic outcomes of ability grouping among junior high school students in Hong Kong, "Journal of Educational Research, vol. 96, no. 4, pp. 241-254, 2003.

[4] C. H. Hung," A study on the teaching strategies for English teachers in vocational high school," in Proc. Seventh ESL International Conference in R.O.C., Taipei, 2001, pp. 547-557.

[5] Y. Kim, "Implementing ability grouping in EFL contexts: Perceptions of teachers and students," Language Teaching Research, vol. 16, pp. 289-315, 2012

[6] J. C. Richards, "Dimensions of dialogue: large classes in China," International Journal of Educational Research, vol. 29, pp. 739-761, 1999.

[7] J. P. Robinson, "Evidence of a differential effect of ability grouping on the reading acievement growth of language- minority Hispanics,' Educational Evaluatuon and Policy Analysis, vol. 30, pp. 141-180, 2008.

[8] K. G. Welner and J. Oakes, "Ability grouping: The new susceptibility of school tracking system to legal challenges," Harrard Educational Review, vol. 66, no. 3, pp. 451-471, 2010.

[9] H. H. Lee, "The school policies for the effective English teaching," in Proc. Ninth ESL International Conference in R.O.C., Taipei, 2000, pp. 574-585.

[10] T. Y. Chan, "Grouping method for cooperative learning based on immersive virtual reality," M.A. thesis, Chung Yuan University, Taiwan, 2002.

[11] H. M. Chang, "The effects of different grouping methods on learning attitudes and achievement in the cooperative learning," master's thesis, Tamkang University, Taiwan, 2003.

[12] R. Clement, Z. Dornyei, and K. A. Noels, Designing groupwork: Strategies for the heterogeneous classroom. New York: Teachers College Press, 1994.

[13] S. C. Chueng, "The effects of gender and mixed-abilities in the learning achievement and attitude in computer cooperative learning," Journal of Elementary Education, vol. 2, pp. 81-105, 1996.

[14] C. C. Fung, "The effects and effectiveness of applying grouping methods to cooperative learning," master's thesis, Tamkang University, Taipei, 2001

[15] S. H. Cheng, "Study on student team forming in a collaborative learning environment," master's thesis, National ChiaoTung University, Taiwan, 2000.

[16] D. H. Wulff, J. D. Nyquist, and R. D. Abbott, "Students' perceptions of large classes," in M. Weimer (Ed.), Teaching large classes well. New directions for teaching and learning, vol. 32, San Francisco: Jossey-Bass, 1987.
[17] D. D. Holt, "Cooperative Learning for Students from Diverse Language Backgrounds: An Introduction," in D. D. Holt (Ed.), Cooperative learning: A response to linguistic and cultural diversity, Washington, D.C.: Delta Systems and Center for Applied Linguistics, 1993, pp. 1-8.

[18] T. Y. Chan, "Grouping method for cooperative learning based on immersive virtual reality," master's thesis, Chung Yuan University, Taiwan, 2002.

[19] Y. L. Chang, "A study on optimal grouping of cooperative learning by using genetic algorithm," master's thesis, National Tainan Normal College, Taiwan, 2001

[20] C. L. Lee and Y. J. Hung, "A new method for innovative curricula in the EFL," Journal of Nankai, vol. 5, pp. 355-363, 2003.

[21] C. L. Lee, "A study on effects of applying intelligent clustering to cooperative learning on students' academic achievement and attitudes in junior college English class," Handbook of 2004 International Symposium on English Teaching and Curriculum Planning in Taiwan, 2004, pp.137-152.

[22] Ministry of Education. (January, 2005). National education development and reform for the new millennium. [Online]. Available: http://www.eje.edu.tw/l-english/ejeEnglish.asp

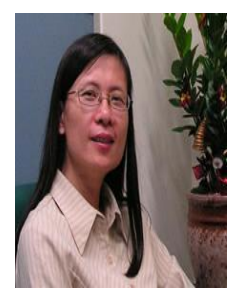

Chin-Ling Lee received the B. A. degree in English from Tamkang University, Taiwan, R. O. C., in 1986, the M. A. degree in English from University of Central Missourri, U. S. A., in 1990, and the Ph. D. degree in industrial education from National Taiwan Normal University, Taiwan, R. O. C. Currently, she is associate professor of International Trade Department, National Taichung University of Science and Technology, Taichung City, Taiwan, R. O. C. Her current research interests are e-learning education, English for specific purposes, and English teaching and learning.

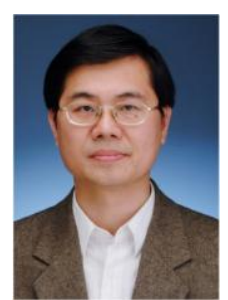

Cheng-Jian Lin received the Ph.D. degrees in electrical and control engineering from the National Chiao-Tung University, Taiwan, R.O.C., in 1996. Currently, he is a Distinguished Professor of Computer Science and Information Engineering Department, National Chin-Yi University of Technology, Taichung County, Taiwan, R.O.C. His current research interests are soft computing, pattern recognition, intelligent control, image processing, bioinformatics, and Android/iPhone program design.

Dr. Lin is an Editorial Board of Applied Computational Intelligence and Soft Computing from 2011, an Editorial Board of Computational Intelligence and Neuroscience from 2011, an Editorial Board of Int'l journal of Control Engineering and Technology from 2011, and an Editorial Board Member of the Open Cybernetics and Systemics Journal from 2010. Dr. Lin is a member of the Phi Tau Phi, the Chinese Fuzzy Systems Association (CFSA), the Chinese Automation Association, the Taiwanese Association for Artificial Intelligence (TAAI), the IEEE Systems, Man, and Cybernetics Society, and the IEEE Computational Intelligence Society. $\mathrm{He}$ is an executive committee member of the Taiwanese Association for Artificial Intelligence (TAAI) from 2003 to 2010 . He is an executive committee member of the Chinese Fuzzy Systems Association (CFSA) from 2007.

Dr. Lin has received several honors and awards, including the 2006 Outstanding Paper Award of the 11th Conference on Artificial Intelligence and Applications, the 2007 Outstanding Paper Award of the 12th Conference on Artificial Intelligence and Applications, the 2006 Best Paper Award of International Trans. on Computer Science and Engineering (Vol. 32, No. 1) the First Place of the $14^{\text {th }}$ College Contest of IT Services Innovation 2009, the Silver Prize of International Trade Fair Ideas-Invention-New Productions Nuremberg 2009 (iENA 2009), and the Silver Prize of Seoul International Invention Fair 2010 (SIIF 2010). 